\title{
THE RED CROSS AND THE GENEVA CONVENTIONS - 60 YEARS ON
}

\author{
New Zealand Red Cross*
}

\section{ORIGINS AND SIGNIFICANCE}

In 2009, the world marked the 60th anniversary of the Geneva Conventions. Although it is now six decades since they were agreed, they remain as relevant if not more so, especially given today's humanitarian challenges.

World War II was a conflict distinguished by violence unleashed on a hitherto unprecedented scale - not only between combatants, but also directed against civilians, who suffered casualties through horrors that echoed the 17th century's Thirty Years' War. The discovery of the Nazi concentration camps and the mass extermination carried out within their walls added yet another layer of horror to the tragedy that the world lived through from 1939 to 1945 . To transmit the sentiment of the time, a telling quotation from General Eisenhower while visiting a Nazi death camp in 1945 will suffice: "[t]he world must know what happened, and never forget."1

There can, therefore, be no doubt that the decision to draft the Geneva Conventions of 1949 was strongly shaped by World War II and that these Conventions sought to fill the gaps in international humanitarian law grievously exposed by that conflict.

However, improvements in the protection of victims of war (in particular civilians) had been under discussion well before the outbreak of World War II. Since the early 1920s, the International Committee of the Red Cross (ICRC) had considered various projects - one of which was designed to protect the civilian population against the effects of war, in particular aerial warfare. Yet, it was not to be. A lack of will on the part of governments meant that Switzerland was unable to announce the diplomatic conference until June 1939 - scheduled for early 1940. The rest is history.

* New Zealand Red Cross is one of 186 national Red Cross or Red Crescent Societies in the world. In New Zealand, New Zealand Red Cross works closely with the International Committee of the Red Cross (ICRC) in the promotion of international humanitarian law and provides ICRC with trained aid workers, many of these health professionals, for deployment in contexts such Iraq, South Ossetia, Afghanistan, Pakistan and the Sudan.

1 Philipp Spoerri, Director of International Law ICRC "The Geneva Conventions of 1949: Origins and Significance" (Public Address at Ceremony to celebrate the 60th anniversary of the Geneva Conventions, Geneva, 12 August 2009) available at <www.icrc.org $>$. 
During World War II, the ICRC's energies were largely taken up by its activities in the field, but as the guardian of international humanitarian law, it continued to discuss the possibility of relaunching the process of revising and extending the law of Geneva as soon as possible.

In February 1945, therefore, even before the end of hostilities, the ICRC had announced to governments and national Red Cross and Red Crescent Societies its intention to revise the existing rules and to seek the adoption of new conventions; this against a background of uncertainty as to the place of humanitarian rules in an era of total warfare.

Overcoming these understandable apprehensions, the ICRC organised in September 1945 the Preliminary Conference of National Red Cross Societies in Geneva to study existing international instruments protecting victims of war, followed by a conference of government experts in 1947.

The ICRC informed the Swiss authorities of its wish to convene a major diplomatic conference. The conference duly opened on 21 April 1949 in the presence of representatives from 64 countries, from virtually every State in the world at that time. According to various eye-witness accounts, no conference had ever been so well prepared. Nevertheless, it took almost four months to complete its work, which surprised the public and made the conference longer than anticipated. However, there was a sense of camaraderie and frank discussion, even as the world entered a deepening Cold War. The following four conventions were adopted as a result of these proceedings:

- Geneva Convention for the Amelioration of the Condition of the Wounded and Sick in Armed Forces in the Field (First Convention); ${ }^{2}$

- Geneva Convention for the Amelioration of the Condition of the Wounded, Sick and Shipwrecked Members of Armed Forces at Sea (Second Convention); ${ }^{3}$

- Geneva Convention relative to the Treatment of Prisoners of War (Third Convention); ${ }^{4}$

- Geneva Convention relative to the Protection of Civilian Persons in Time of War (Fourth Convention). ${ }^{5}$

Overall, these four texts greatly expanded the scope of international humanitarian law. One of the greatest advances was the adoption of the Fourth Convention, which offered civilians a similar

2 Convention (I) for the Amelioration of the Condition of the Wounded and Sick in Armed Forces in the Field (opened for signature 12 August 1949, entered into force 21 October 1950).

3 Convention (II) for the Amelioration of the Condition of Wounded, Sick and Shipwrecked Members of Armed Forces at Sea (opened for signature 12 August 1949, entered into force 21 October 1950).

4 Convention (III) relative to the Treatment of Prisoners of War (opened for signature 12 August 1949, entered into force 21 October 1950).

5 Convention (IV) relative to the Protection of Civilian Persons in Time of War (opened for signature 12 August 1949, entered into force 21 October 1950). 
protection to other victims of war and finally closed one of the most serious gaps exposed by World War II and all other international instruments that had preceded it. Article 3, common to the four Geneva Conventions and referred to as Common Article 3, represented another significant milestone, extending the principles of the Geneva Conventions to non-international armed conflicts.

The Geneva Conventions immediately proved a major success. They entered into force on 21 October 1950 after the first two ratifications. They were ratified by 74 States in the 1950 s and obtained a further 48 ratifications in the 1960s. A wave of 26 new ratifications occurred in the early 1990s, resulting in particular from the break-up of the Soviet Union and the former Yugoslavia and the dissolution of Czechoslovakia. With the last few (seven) ratifications since the year 2000, the applicability of the Geneva Conventions has now become universal, with 194 State parties.

Today, the Geneva Conventions remain the cornerstone of contemporary international humanitarian law. They contain the essential rules protecting persons who are not, or no longer, taking a direct part in hostilities when they find themselves in the hands of an adverse party. As mentioned, these persons include the wounded and sick, the shipwrecked, prisoners of war and civilians, including those living under occupation.

The basic notion underlying the Geneva Conventions is respect for the life and dignity of the individual. Those who suffer in conflict must be aided and cared for without distinction. The Conventions also confirm and strengthen the role of the medical mission - medical personnel, medical units and transports must be respected and protected in all circumstances. This is an indispensable condition to be able to collect and care for the wounded and sick. The principles on which these rules are based are as old as armed conflict itself.

\section{RELEVANCE IN CONTEMPORARY CONFLICTS}

The ongoing relevance of international humanitarian law is supported by the findings of an opinion poll that asked a series of questions on what people in countries affected by war consider acceptable behaviour during hostilities and about the effectiveness of the Geneva Conventions. The survey, commissioned by the ICRC to mark the 60th anniversary of the Geneva Conventions, was conducted by the Ipsos Agency in Afghanistan, Colombia, the Democratic Republic of the Congo, Georgia, Haiti, Lebanon, Liberia and the Philippines. ${ }^{6}$

Most of the roughly 4,000 people surveyed across the eight countries - 75 per cent - said there should be limits to what combatants are allowed to do in the course of fighting. The findings also revealed broad support for the core principles underpinning the Geneva Conventions, and international humanitarian law more generally, by people who actually lived in conflict and violence

6 Our World. Views from the Field. Summary Report: Afghanistan, Colombia, Democratic Republic of The Congo, Georgia, Haiti, Lebanon, Liberia And The Philippines. Opinion Survey and In-Depth Research, 2009 (Ipsos Agency and ICRC, Geneva, 2009). 
affected countries. However, the survey also revealed that the perceived impact of the rules on the ground was far weaker than was support for them. This indicated that people in war-affected countries wanted to see better respect for, and implementation of, international humanitarian law.

Of course, for the most part the Geneva Conventions only regulate international armed conflicts, including situations of military occupation. While it is true such conflicts and occupations are fortunately - not as frequent as in the past, they have not completely disappeared either. Recent examples include the conflicts in Afghanistan (2001-2002), the Iraq war (2003-2004), the conflict in southern Lebanon (2006) and the conflict between Russia and Georgia (2008).

The regulation of the conditions of detention is fundamental in saving the lives and ensuring the well-being of detainees. It is on the basis of the rules on the conditions of detention outlined in the Geneva Conventions that the ICRC can carry out its work in the field, including its visits to detainees. The purpose of these visits is to prevent enforced disappearances, extra-judicial executions, torture and other cruel, inhuman or degrading treatment or punishment, to ensure due process, to monitor the material conditions of detention, and to restore family links inter alia through the exchange of Red Cross messages. Vital to these functions is the zealous upholding of the principles of impartiality, neutrality and independence.

A few figures from recent international armed conflicts illustrate how the Geneva Conventions remain relevant for war victims. In the course of the conflict between Eritrea and Ethiopia, the ICRC visited, in the year 2000 alone, more than 1,000 Ethiopian prisoners of war and 4,300 civilian internees. In addition, the ICRC exchanged 16,326 messages between Ethiopian and Eritrean prisoners of war and their families. The ICRC also organised safe passage across the front lines for 12,493 civilians of Ethiopian origin. In cooperation with the Red Cross Society of Eritrea, the ICRC distributed aid to more than 150,000 civilians affected by the conflict and provided surgical supplies to treat 10,000 war-wounded, in cooperation with the Ministry of Health. ${ }^{7}$

The value of the Geneva Conventions lies not just in the tangible humanitarian support that they deliver but, as importantly, the greater evil they have helped to prevent. For example, the ICRC knows from experience that the distinctive emblems of the red cross and red crescent have protected countless hospitals, medical units and personnel as well as innumerable wounded and sick. In recent years, the ICRC unfortunately has witnessed far too many examples of flagrant violations of the distinctive emblems and the medical mission. However, without the rules contained in the Geneva Conventions, the situation would be far worse for the victims and far more difficult for those who seek to assist and protect.

Are the Geneva Conventions equally relevant for armed conflicts of a non-international character? These types of conflicts are predominant today. The situations that come to mind include

7 Spoerri, above n 1. 
the Darfur region in the Sudan, Colombia, eastern Democratic Republic of Congo or today's Afghanistan, Iraq and Somalia. Common Article 3 of the Geneva Conventions deals with any armed conflict not of an international character. Thus, any armed conflict that it is not an inter-State conflict falls within the scope of Common Article 3. Although this is just one provision, it contains the essential rules of international humanitarian law in a nutshell:

- it requires humane treatment for all persons in enemy hands, regardless of how they may be legally or politically classified or in whose custody they may be; as a result, no one may be placed or treated outside of Common Article 3, bereft of all protection - whether civilian or soldier, all are covered;

- it requires that the wounded, sick and shipwrecked be collected and cared for;

- it grants the ICRC the right to offer its services to the parties to the conflict; on the basis of Common Article 3, the ICRC systematically requests access to persons deprived of their liberty in connection with non-international armed conflicts, and such access is generally granted; and,

- finally, it recognises that the application of these rules in no way affects the legal status of the parties to the conflict.

Common Article 3 is not just an article like any other, but a mini-convention within the Geneva Conventions. The International Court of Justice has called Common Article 3 a reflection of "elementary considerations of humanity". ${ }^{8}$ In the light of the prevalence of non-international armed conflicts today, this remains a provision of utmost importance.

Since the adoption of the Geneva Conventions in 1949, they have been supplemented and developed by three Additional Protocols. The first two were adopted in 1977, and the third more recently in 2005 introduced a new protective emblem, the red crystal. ${ }^{9}$

The 1977 Additional Protocols were drawn up essentially as a response to changes in warfare, most notably the expansion of guerrilla warfare, and the increased suffering of civilians in armed conflict due in part to developments in weapons technology. They introduced essential rules relating to the conduct of hostilities and the methods and means of warfare, the aim of which was to

8 Military and Paramilitary Activities in and against Nicaragua (Nicaragua $v$ United States of America) (Merits) [1986] ICJ Rep 14 at 104.

9 Protocol Additional to the Geneva Conventions of 12 August 1949, and relating to the Protection of Victims of International Armed Conflicts (Protocol I) (opened for signature 8 June 1977, entered into force 7 December 1978); Protocol Additional to the Geneva Conventions of 12 August 1949, and relating to the Protection of Victims of Non-International Armed Conflicts (Protocol II) (opened for signature 8 June 1977, entered into force 7 December 1978); and, Protocol Additional to the Geneva Conventions of 12 August 1949, and relating to the Adoption of an Additional Distinctive Emblem (Protocol III) (opened for signature 8 December 2005, entered into force 14 January 2007). 
strengthen protection for civilians. In particular, they formulated the important principle of distinction between civilians and combatants and between civilian objects and military objectives. They have also expanded the list of fundamental guarantees applicable to all persons in the power of an adverse party. Additional Protocol I was thus designed to supplement, update and formalise legal restraints on the means and methods of warfare to ensure more effective protection of the civilian population.

The 1977 Additional Protocols were also a response to the proliferation of internal armed conflicts. Indeed, Additional Protocol II was the first treaty ever devoted exclusively to the protection of the victims of such conflicts, elaborating on the protection provided in Common Article 3.

While the 1949 Geneva Conventions have been universally ratified, the Additional Protocols have not. At present, 170 States are party to Additional Protocol I and 165 States to Additional Protocol II. Some States that have not ratified the Additional Protocols have nevertheless incorporated aspects of them into military manuals.

\section{CURRENT CHALLENGES: THE PROTECTION OF HEALTH WORKERS}

Currently, it is the lack of respect for existing rules that remains the main challenge as international humanitarian law is frequently violated in armed conflicts around the world.

One of the major challenges is the protection of both health workers and the wounded and sick. The ICRC and national societies have become deeply alarmed that the wounded and sick in armed conflict and other situations of violence do not receive the care and protection they require. Frequently, they are denied health care through deliberate action or omission, or owing to serious disruptions in the provision of care and the delivery of medicines, medical equipment and other medical supplies.

At the same time, the ICRC and national societies are equally alarmed at frequent attacks committed against health workers, facilities and transport. Some healthcare teams of national societies have also become targets as they administer to the needs of the wounded and sick in armed conflict and other situations of violence.

A further concern is the misuse of medical facilities and the emblems of the Movement to carry out military operations that place civilians, the wounded and sick, and healthcare personnel in danger. Such attacks contravene international humanitarian law and human rights law. They also highlight the importance for all armed forces and groups to ensure the relevant norms are implemented in military practice. 
A substantial part of international humanitarian law today deals with rules for caring for and protecting the wounded and sick. More than 150 years after the Battle of Solferino, ${ }^{10}$ the need to ensure and protect the medical mission in armed conflict and other situations of violence is as vital as ever.

The ICRC and national societies, with the support of the International Federation of Red Cross and Red Crescent Societies, have a particular role to play in promoting international humanitarian law and supporting States in their efforts to incorporate that law in their national legal systems and practice.

In armed conflict and other situations of violence, the ICRC, in accordance with its mandate, has a critical role in reminding the parties to conflict of their obligations under international humanitarian law and other applicable legal regimes to respect health care and foster its safe and speedy delivery.

However, the ICRC is only part of the solution. Governments must commit to implementing measures in their domestic law and military practice to ensure the identification of medical personnel and facilities, the protection of the distinctive emblems, the dissemination and training in the field of international humanitarian law and the repression of serious violations of relevant international norms in their domestic courts consistent with international law.

Similarly, national societies must strengthen their efforts to promote, disseminate and support the national implementation of international humanitarian law to respect and protect health care in armed conflict and other situations of violence. In addition, the capacity of national societies must be strengthened in countries affected by conflict and violence in order to meet their health needs.

\section{OTHER CHALLENGES}

The extent to which armed conflicts have evolved over the past 60 years cannot be underestimated. It almost goes without saying that contemporary warfare rarely consists of two well-structured armies facing each other on a geographically defined battlefield. Lines have become increasingly blurred between various armed groups and between combatants and civilians - civilian men, women and children - who are increasingly the main victims. International humanitarian law has necessarily adapted to this changing reality. The adoption of the first two Additional Protocols in 1977, with the rules they established on the conduct of hostilities and on the protection of persons affected by non-international armed conflict, is just one example. Specific rules prohibiting or regulating weapons such as anti-personnel mines and, more recently, cluster munitions are further examples of the adaptability of international humanitarian law to the realities on the ground.

10 For an analysis of the Battle of Solferino and its impact on the development of international humanitarian law, particularly the genesis of the International Committee of the Red Cross, see KJ Keith "Tutti Fratelli? Perspectives and Challenges for International Humanitarian Law" (2010) 41 VUWLR 123. 
The traumatic events of 11 September 2001, and its aftermath, and the 2002 Bali bombing set a new test for international humanitarian law. The polarisation of international relations and the humanitarian consequences of what has been referred to as the "global war on terror" have posed a huge challenge. The proliferation and fragmentation of non-State armed groups, and the reality that some reject the premises of international humanitarian law, have posed another. These challenges effectively expose international humanitarian law to rigorous cross-examination by a wide range of actors, including the ICRC, to test its adequacy as a legal framework for the protection of victims of armed conflict.

The result of this at times arduous process has been a resounding reaffirmation of the relevance and adequacy of international humanitarian law in preserving human life and dignity in armed conflict. However, the nature of armed conflict and of its causes and consequences is continuing to evolve. International humanitarian law must also evolve.

Ongoing challenges to international humanitarian law include the conduct of hostilities. Civilians have progressively become more involved in activities closely related to actual combat. At the same time, combatants do not always clearly distinguish themselves from civilians, neither wearing uniforms nor openly carrying arms. They mingle with the civilian population. Civilians are also used as human shields. To add to the confusion, in some conflicts, traditional military functions have been outsourced to private contractors or other civilians working for State armed forces or for organised armed groups. These trends are, if anything, likely to increase in the years ahead.

The result is that civilians are more likely to be targeted - either mistakenly or arbitrarily. Military personnel are also at increased risk: since they cannot properly identify their adversary, they, too, are vulnerable to attack by individuals who to all appearances are civilians.

This lack of clarity costs lives. In an effort to help remedy this situation, the ICRC worked for six years with a group of more than 50 international legal experts from military, academic, governmental and non-governmental backgrounds. The end result of this long and intense process was a substantial guidance document published in 2009 that serves to shed light as to who is considered a civilian for the purpose of conducting hostilities, what conduct amounts to direct participation in hostilities, and which particular rules and principles govern the loss of civilian protection against direct attack. ${ }^{11}$

Direct participation in hostilities is not the only concept relating to the conduct of hostilities to benefit from further clarification. Differences exist over the interpretation of other key notions such as "military objective", the "principle of proportionality" and "precaution".

11 Nils Melzer Interpretive Guidance on the Notion of Direct Participation in Hostilities under International Humanitarian Law (ICRC, Geneva, 2009). 
The debate has been prompted in part by the growing number of military operations conducted in densely populated urban areas, often using heavy or highly explosive weapons, which have devastating humanitarian consequences for civilian populations. A further factor is the increasing development and use of unmanned aerial vehicles, or "drones", in theatres of conflict.

\section{CONCLUSION}

In 1949, the Geneva Conventions were born out of the horrors experienced by millions of people during World War II and its aftermath. The essential spirit of the Geneva Conventions - to uphold human life and dignity even in the midst of armed conflict - remains as vital now as it was then.

The ICRC and national societies alone cannot ensure respect for the Geneva Conventions. This task requires the broad and ongoing vigilance and commitment of national governments, armed forces and armed groups. 
